\title{
近赤外分光法によるモモ果実の渋味の評価
}

\author{
高野和夫 ${ }^{1 *}$ ・妹尾知憲 ${ }^{1} \cdot$ 海野孝章 ${ }^{1, \mathrm{a}} \cdot$ 笹邊幸男 ${ }^{1} \cdot$ 多田幹郎 $2, \mathrm{~b}$ \\ 1 岡山県農業総合センター農業試験場 709-0801 赤磐市神田沖 \\ 2 岡山大学大学院自然科学研究科 $700-8530$ 岡山市津島中
}

\section{Distinction of Astringency in Peach Fruit Using Near-Infrared Spectroscopy}

\author{
Kazuo Takano $^{1 *}$, Tomonori Senoo ${ }^{1}$, Takaaki Uno ${ }^{1, a}$, Yukio Sasabe ${ }^{1}$ and Mikiro Tada ${ }^{2, b}$ \\ ${ }^{I}$ Agricultural Experiment Station, Okayama Prefectural Agriculture Center, Akaiwa, Okayama 709-0801 \\ ${ }^{2}$ Graduate School of Natural Science and Technology, Okayama University, Okayama 700-8530
}

\begin{abstract}
To establish a nondestructive method of measuring astringency in peach fruit, near-infrared spectroscopy (NIRS) was attempted. In the organoleptic test, significant correlation existed between astringency and polyphenol concentration which ranged from $30 \mathrm{mg}$ to $220 \mathrm{mg} \cdot 100 \mathrm{~g}^{-1} \mathrm{FW}$. Strong astringency was sensed when the polyphenol concentration in the fruit was higher than $110 \mathrm{mg} \cdot 100 \mathrm{~g}^{-1} \mathrm{FW}$. In analysis of the model solution of catechin and chlorogenic acid which are the main components of polyphenol in fruit using the second derivative transmittance spectra from $1100 \mathrm{~nm}$ to $2500 \mathrm{~nm}$, it was found that there was a high correlation between absorbance around $1664 \mathrm{~nm}$ and $1730 \mathrm{~nm}$ and concentration of the solution. Then measurement of intact fruit by NIRS was performed using the second derivative reflectance spectra scanning from $1100 \mathrm{~nm}$ to $2500 \mathrm{~nm}$. As a result of performing multiple regression analysis, the absorbance at $1720 \mathrm{~nm}$ showed high correlation with polyphenol. In the calibration equation development, the highest predicted correlation coefficient (r) was 0.80 and the bias-corrected standard error of prediction (SEP) was $14.7 \mathrm{mg} \cdot 100 \mathrm{~g}^{-1} \mathrm{FW}$ for polyphenol. It can be concluded that NIRS is a promising method for determining the astringency of peach fruit.
\end{abstract}

Key Words : nondestructive measurement, organoleptic test, polyphenol

キーワード：非破壊測定，官能検査，ポリフェノール

\section{緒言}

環境条件や栽培条件により，モモ果実が時として強烈な 渋味を呈することはよく知られている。渋味の発生要因と して, 品種特性のほか果実肥大第 3 期の土壤乾燥や低温が 挙げられ，特にこの時期の乾燥が密接に関係するとされて いる（久保田ら，1990）。渋味の発生程度は土性や潅水設備 の有無に起因する園地間差があるものと推察されるが, 強 烈な渋味は，久保田・岩瀬（1993）の報告にもあるように， 病害虫や日焼けによるモモ樹の幹や枝の損傷による影響も 大きいと考えられる。したがって，淽味の強いモモの発生 防止には，病害虫や日焼けによる幹の損傷を防止するよう な栽培管理を行うことが重要であるが，既に損傷が激しい 樹に対しては, 速やかな改植が必要と考える. しかし, 改

2006 年 4 月 18 日 受付. 2006 年 5 月 26 日 受理.

本試験は農林水産省の地域重要新技術開発促進事業の一環とし

て行った.

* Corresponding author. E-mail: kazuo_takano@pref.okayama.lg.jp

a 退職

$\mathrm{b}$ 現在 : 中国学園大学
植時期は生産者個々の判断にゆだねられ，このため市場に は強烈な渋味を有する果実が混入し，消費者からのクレー ムの原因となっている．ところが，現在の出荷システムで は, いったん果実が選果場に出荷され共同選果に移される と，もはや渋味の強いモ乇を外観から判断することは不可 能である。このため渋味の強いモモを非破壊的に選別でき る出荷システムの開発が強く望まれている. 本報は, 近赤 外分光法によるモモ果実の渋味の非破壊判別方法について 検討したものである.

\section{材料および方法}

\section{1. 供試果実}

1994 年から 1996 年にかけて, 岡山県立農業試験場なら びに農家のモモ園で有袋栽培された 8 品種の収穫果実を供 試した，果実の採取に当たっては，渋味の強い果実を入手 するために，幹の損傷の大きい樹や，久保田ら（1993）の 報告を参考にして人為的に果実発育第 2 期に環状剥皮処理 を施した樹からも採取した。 これらの果実について，近赤 外スペクトルを測定後, 屈折計示度, 全ポリフェノール濃 度拉よび渋味の程度を調査した，果汁の $400 〜 2500 \mathrm{~nm}$ 透 
過スペクトルの解析には ‘白鳳”, “清水白桃”, “白桃”, ‘勘 助白桃”, “白麗” および “白陽”を, 果実の $400 \sim 1100 \mathrm{~nm}$ 反射スペクトルの解析には '都白鳳”, “白鳳”, “清水白桃” および ‘白桃”を，また，果実の $1100 〜 2500 \mathrm{~nm}$ 反射スペ クトルの解析には “清水白桃”, “白陽”沏よび ‘まさひめ’ を用いた，渋味は，官能検查により以下の 5 段階で評価し た，無（0）: 渋味を感じない，微（1）：わずかに渋味を感 じる, 中（2）: 明らかに渋味を感じる, 強（3）: 強く渋味 を感じる，甚（4）：橴柿のような強烈な渋味を感じる.

\section{2. 近赤外スペクトルの測定と解析}

モモ果汁の透過スペクトルは, 近赤外分光光度計 (NIRSystems，6500) により，400〜1100 nm では光路長 $10 \mathrm{~mm} ， \quad 1100 \sim 2500 \mathrm{~nm}$ では光路長 $2 \mathrm{~mm}$ の石英セルを用 いて測定し, 全 131 サンプルの中から 53 サンプルを抽出し て重回帰分析により検量線を作成するとともに, 残りの 78 サンプルで検量線の評価を行った。 な拈，スペクトルの測 定には，酸化褐变を防止するために電子レンジで加熱処理 した果実から搾汁した果汁を用いた。

モモ果実の $400 \sim 1100 \mathrm{~nm}$ の反射スペクトルは，近赤外 分光光度計 (NIRSystems, 6500) により, 同軸光ファイバー を用いて暗箱内で測定し, 全 151 サンプルについて全品種 ならびに品種別に重回帰分析した.

モモ果実の $1100 \sim 2500 \mathrm{~nm}$ の反射スペクトルは, 山口県 農業試験場に設置されている近赤外分光光度計 （NIRSystems, 6250）により，同波長域が測定可能な同軸光 ファイバー（KDDI）を用いて暗箱内で測定し，43 サンプ ルを用いた重回帰分析と PLS（Partial Least Squares）回帰分 析により検量線を作成し，35サンプルで検量線の評価を 行った.

ポリフェノールの吸収波長域を明らかにするため, モモ 果実のポリフェノールの主要な構成成分 (中林, 1968, 1995; Tomas-Barberan ら，2001）である（+）カテキンとクロロゲ ン酸 (いずれも東京化成) の $0,50,100,150$ お。び $200 \mathrm{mg}$ ・ $100 \mathrm{~mL}^{-1}$ 水溶液を, $400 \sim 1100 \mathrm{~nm}$ では光路長 $20 \mathrm{~mm}, 1100$ 〜2500 nm では光路長 $2 \mathrm{~mm}$ の石英セルを用いて測定した.

スペクトルの測定は何れの試験でも気温 $22 \sim 24^{\circ} \mathrm{C}$ の 室内で行った。 回帰分析には何孔も2 次微分スペクト ル $($ Segment $=20, \mathrm{Gap}=0)$ を用い, 重回帰分析は NSAS (NIRSystems) で 4 波長を上限に, PLS 回帰分析は The Unscrambler (Camo) で Full cross validation 法により行った. なお，検量線評価時の標準誤差（SEP）は，バイアス補正 済夕の標準誤差（従来法による分析値と近赤外推定值との 残差の標準偏差）で表した。

\section{3. ポリフェノールの分析}

モモ果実のポリフェノールの分析には, 果皮を除いた果 肉 $10 \mathrm{~g}$ を, 酸化褐変を防止するために電子レンジで加熱し た後に冷凍し, 後日解凍後に脱塩水を加兄磨砕した後 20 分 間惹沸し， $100 \mathrm{~mL}$ に定容後濾過し，その 10 倍希釈液を用 いた。 ポリフェノールの分析は, 久保田ら（1988）の方法
に準じ，フォーリン・デニス法（中林，1995）で行った. すなわち, 上述のサンプル抽出液 $5 \mathrm{~mL}$ に, フェノール試 薬（キシダ化学）の 5 倍希釈液 $5 \mathrm{~mL}$ を加光，最後に $10 \%$ 炭酸ナトリウム溶液 $5 \mathrm{~mL}$ を加えて擋挥した後, 1 時間以上 放置後 $700 \mathrm{~nm}$ の吸光度を測定し，（+）カテキン水溶液に よる検量線から算出した値を全ポリフェノール濃度とし た。また，1990年には“清水白桃”の果実成熟期に打ける 全ポリフェノール濃度の変化を調査するとともに，果実の 部位別の全ポリフェノール濃度と高分子ポリフェノール濃 度を調査した。な抢，部位別のポリフェノール濃度の測定 では，抽出液について除タンニン処理を行った後に同様の 分析を行い, ここで得られた值を前述の全ポリフェノール から差し引き，これを高分子ポリフェノールとした。除夕 ンニン処理は, 抽出液 $25 \mathrm{~mL}$ に $2 \%$ ゼラチン水溶液 $7.5 \mathrm{~mL}$ を加光擋拌し, 酸性飽和食塩水で $50 \mathrm{~mL}$ に定溶したのち, カオリン半匙を加宎擋拌しろ過することにより行った（京 都大学農学部農芸化学教室, 1957).

モモ果汁のポリフェノールの分析に打いては，果実を電 子レンジで加熱した後に冷凍し, 後日解凍後に搾汁した果 汁の 100 倍希釈液を用い，果肉と同様にポリフェノールの 分析を行った。

\section{結 果}

\section{1. ポリフェノール濃度と渋味との関係}

モモの渋味は果肉中の全ポリフェノール濃度が高いほど 強く感じる傾向にあり，“白鳳” の場合には両者の間に渋味 官能検查值 $=1.64 \times \operatorname{Ln}($ 全ポリフェノール濃度 $)-5.35$ の 対数近似式が成り立った (第 1 図). 官能検查值と比較する と, 全ポリフェノール濃度が果肉 $100 \mathrm{~g}$ 当たり約 $50 \mathrm{mg}$ 以 下では渋味を臣とんど感じないが, $50 \sim 80 \mathrm{mg}$ の範囲では わずかに渋味を感じ， $80 \sim 110 \mathrm{mg}$ の範囲では明らかに渋 味を, $110 〜 200 \mathrm{mg}$ の範囲では強い潞味を感じ, さらに $200 \mathrm{mg}$ 以上では強烈な渋味を感じた。

“清水白桃”に扣ける果実発育第 3 期の全ポリフェノール 濃度の変化を第 2 図に示した。果実 $100 \mathrm{~g}$ 当たりの全ポリ フェノール濃度は収穫約 3 週間前の 7 月上旬には約 $180 \mathrm{mg}$

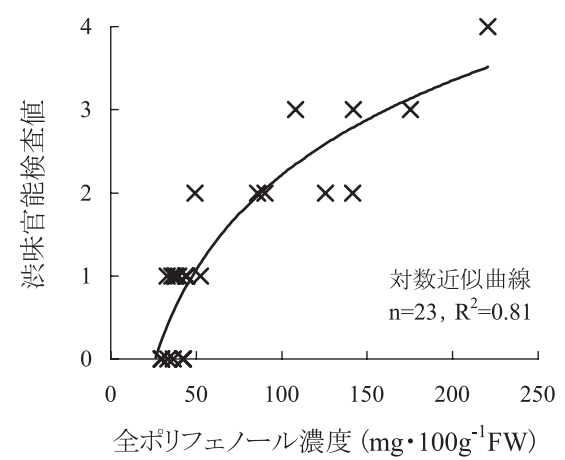

第1図モモ‘白鳳’ のポリフェノール濃度と路味との関係 (渋味 $0:$ 無, $1:$ 微, $2:$ 中, $3:$ 強, $4:$ 甚) 


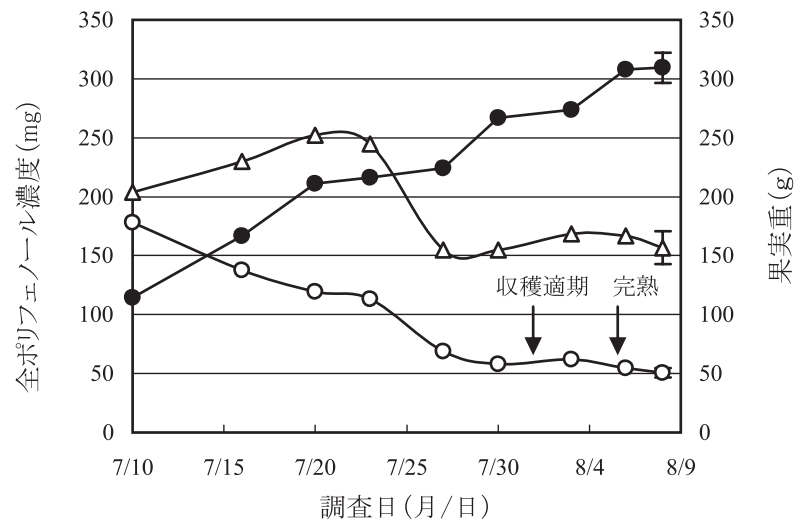

第 2 図モモ “清水白桃”果実の成熟に伴らポリフェノール濃 度の推移（1990 年, $\mathrm{n}=2 \sim 3$, 図中バーは標準誤差）

一ー ポリフェノール濃度（果肉 $100 \mathrm{~g}$ 当たり）

$\triangle$ ポリフェノール含量（1 果実当たり）

- 果実重

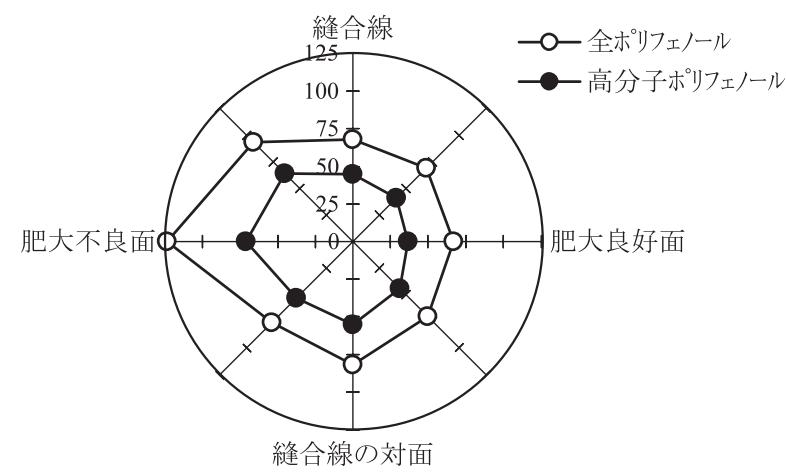

第 3 図モモ“清水白桃”果実の部位別のポリフェノール濃度 $\left(\mathrm{n}=2, \mathrm{mg} \cdot 100 \mathrm{~g}^{-1} \mathrm{FW}\right)$

であったが，果実の成熟に伴って徐々に減少し，収穫期の 8 月上旬には約 $50 \mathrm{mg}$ に低下した。 この間, 果実重は $115 \mathrm{~g}$ から $310 \mathrm{~g}$ に増加した。このため，1果実当たりの全ポリ フェノール含量は, 7 月上旬が約 $200 \mathrm{mg}, 8$ 月上旬が約 $150 \mathrm{mg}$ であった.

果実の部位別のポリフェノール濃度を分析した結果を第 3 図に示した。果実の縫合線に対し左右の肥大に差がある 果実では，肥大が勝る面に比べ，肥大が劣る面の果肉には 全ポリフェノール濃度ならびに高分子ポリフェノール濃度 がともに高かった。

\section{2. 果汁を用いた近赤外分光法による解析}

モモ果実のポリフェノールの主要な構成成分であるカテ キンとクロロゲン酸の吸収波長を, それぞれの水溶液で解 析したところ，カテキン水溶液の $400 \sim 1100 \mathrm{~nm}$ 透過スペ クトルでは, 水溶液の褐色を反映したものと推察される $500 \mathrm{~nm}$ 付近に相関の高い波長域が認められた. 1100 $2500 \mathrm{~nm}$ 透過スペクトルに打いては, カテキンでは $1664 \mathrm{~nm}$ 付近の波長域との相関が最も高く, この他に $1546 \mathrm{~nm}$, $1738 \mathrm{~nm}$ 打よび $2154 \mathrm{~nm}$ 付近の波長域との相関が高かった

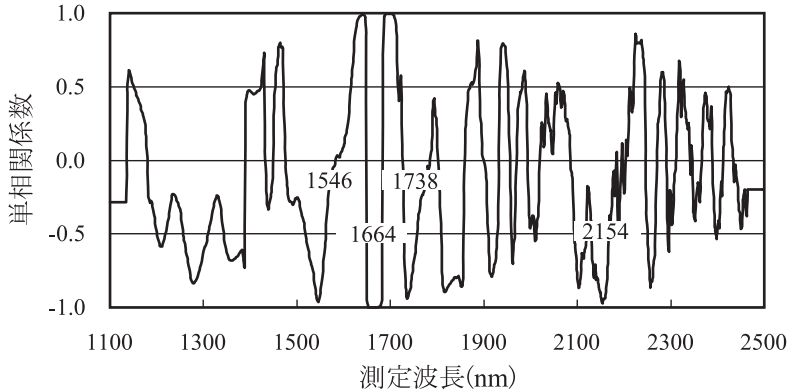

第 4 図 カテキン水溶液の2次微分吸光度とカテキン濃度との 単相関係数プロット

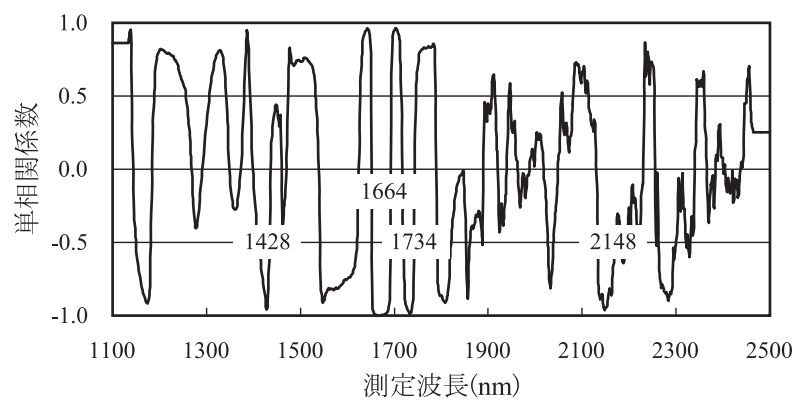

第 5 図クロロゲン酸水溶液の 2 次微分吸光度とクロロゲン酸 濃度との単相関係数プロット

(第 4 図).クロロゲン酸では $1664 \mathrm{~nm}$ と $1734 \mathrm{~nm}$ 付近の波 長域との相関が最も高く, この他に $1428 \mathrm{~nm}$ と $2148 \mathrm{~nm}$ 付 近の波長域との相関が高かった（第 5 図).

モモ果汁の透過スペクトルから全ポリフェノール濃度を 推定する検量線の作成を試みたところ，400～1100 nm の 波長域では，全ポリフェノール濃度の推定精度は，924 nm, $798 \mathrm{~nm}, 988 \mathrm{~nm}$ 打よび $764 \mathrm{~nm}$ の 4 波長で相関係数 $\mathrm{r}=0.769$, 標準誤差 SEP = $15.3 \mathrm{mg}$ であった（第 1 表打よび第 6 図）.

一方， $1100 \sim 2500 \mathrm{~nm}$ の波長域では，カテキンやクロロ ゲン酸と相関の高い $1664 \mathrm{~nm}$ に抢ける 2 次微分吸光度とポ リフェノール濃度との単相関は低かったものの, 第 1 波長 に $1664 \mathrm{~nm}$ を選定することにより検量線の推定精度は向上 した．第 1 波長に $1664 \mathrm{~nm}$ を選定した検量線の第 2 波長に は，クロロゲン酸水溶液の解析で高い相関が認められた波 長域に近い $1744 \mathrm{~nm}$ が選択され，第 3 波長 $2272 \mathrm{~nm}$ との組 又合わせによる検量線の推定精度は，検量線評価時の相関 係数 $\mathrm{r}=0.844$, 標準誤差 $\mathrm{SEP}=12.6 \mathrm{mg}$ と高かった（第 1 表 拈よび第 7 図).

\section{3. 果実を用いた近赤外分光法による解析}

モモ果実の反射スペクトルから全ポリフェノール濃度を 推定する検量線の作成を試みたところ，400～1100 nm の 波長域では，全品種を用いて重回帰分析により作成した検 量線の推定精度は低く, 重相関係数 $\mathrm{R}=0.595$, 標準誤差 $\mathrm{SEC}=29 \mathrm{mg}$ であり (第 8 図), 品種別に解析しても精度は さほど向上しなかった（第 2 表）.

一方，1100〜2500 nm の波長域では，1720 nm と打将 
第 1 表 モモ果汁の 2 次微分透過スペクトルによる全ポリフェノール濃度の重回帰分析による推定

\begin{tabular}{clcccrr}
\hline \hline 波長域 $(\mathrm{nm})$ & \multicolumn{1}{c}{ 選定波長 $(\mathrm{nm})$} & $\mathrm{R}^{\mathrm{z}}$ & $\mathrm{SEC}^{\mathrm{y}}$ & $\mathrm{r}^{\mathrm{x}}$ & SEP $^{\mathrm{w}}$ & Bias $^{\mathrm{v}}$ \\
\hline $400 \sim 1100$ & $924^{\mathrm{m}}, 798^{\mathrm{m}}, 988$ & 0.831 & 15.6 & 0.688 & 17.3 & 0.56 \\
" & $924^{\mathrm{m}}, 798^{\mathrm{m}}, 988,764$ & 0.878 & 13.6 & 0.769 & 15.3 & -0.55 \\
\hline $1100 \sim 2500$ & $1664^{\mathrm{m}}, 1744,2272$ & 0.884 & 13.1 & 0.844 & 12.6 & -1.51 \\
" & $1664^{\mathrm{m}}, 1744,2272,2090$ & 0.923 & 10.9 & 0.808 & 14.3 & -3.51 \\
\hline
\end{tabular}

$\mathrm{z}$ 検量線作成時の重相関係数, $\mathrm{n}=53$

$\mathrm{y}$ 検量線作成時の標準誤差, $\mathrm{mg} \cdot 100 \mathrm{~mL}^{-1}$

$\mathrm{x}$ 検量線評価時の単相関係数, $\mathrm{n}=78$

w 検量線評価時の標準誤差, $\mathrm{mg} \cdot 100 \mathrm{~mL}^{-1}$

$\mathrm{v}$ 近赤外推定值と実測值との残差平均

mマニュアルで選択，その他の波長は自動選択

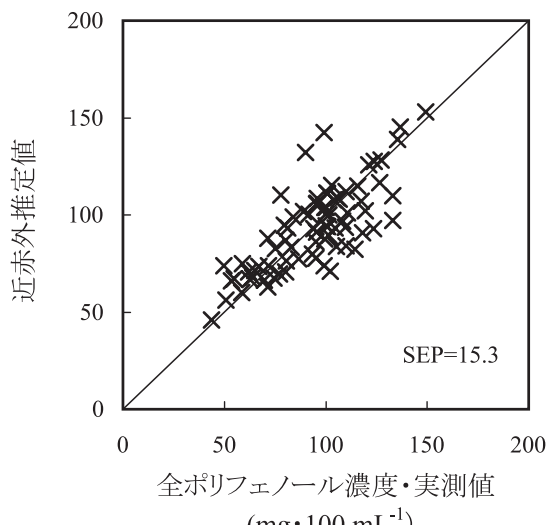

$\left(\mathrm{mg} \cdot 100 \mathrm{~mL}^{-1}\right)$

第 6 図モモ果汁の $400 \sim 1100 \mathrm{~nm}$ の 2 次微分透過スペクトル からの全ポリフェノール濃度推定值と実測値との関係 （検量線波長：924, 798, 988, $764 \mathrm{~nm}$ )

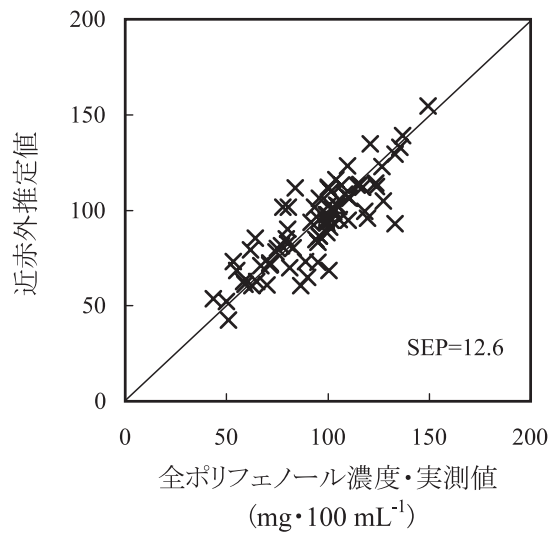

第 7 図モモ果汁の $1100 \sim 2500 \mathrm{~nm}$ の 2 次微分透過スペクト ルからの全ポリフェノール濃度推定値と実測値との関 係（検量線波長：1664, 1744, $2272 \mathrm{~nm}$ )

2 次微分吸光度と全ポリフェノール濃度との間に高い相関 関係 $\mathrm{r}=-0.814$ が認められ (第9図), この $1720 \mathrm{~nm}$ と $1950 \mathrm{~nm}$, $1794 \mathrm{~nm}$ および $2368 \mathrm{~nm}$ との組み合わせにより重回帰分析 で作成した検量線の推定精度は, 検量線作成時の重相関係 数 $\mathrm{R}=0.919$, 標準䛊差 $\mathrm{SEC}=12.5 \mathrm{mg}$, 検量線評価時の標 準誤差 SEP = $14.7 \mathrm{mg}$ であった（第 3 表および第 10 図）。

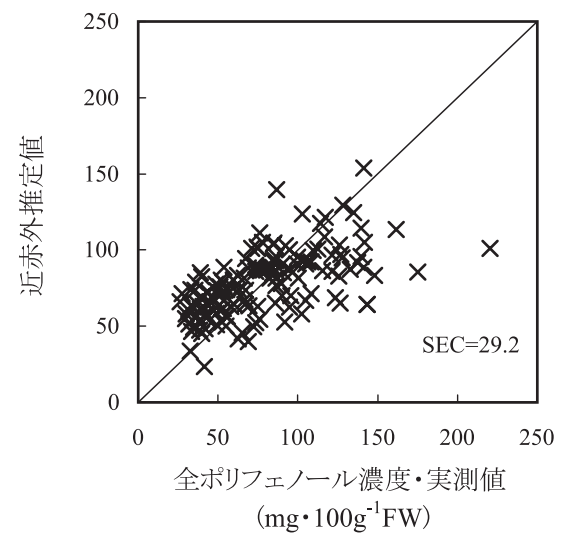

第 8 図モモ果実の $400 \sim 1100 \mathrm{~nm}$ の2 次微分反射スペクトル からの全ポリフェノール濃度推定值と実測值との関係 （検量線波長：858, 480, 946, $1022 \mathrm{~nm}$ )

た, Full cross validation 法によるPLS 回帰分析でも重回帰 分析と同等な推定精度が得られた. PLS 回帰分析では，水 分の吸収域を除外して $1150 \sim 1350 \mathrm{~nm}$ と $1450 \sim 1800 \mathrm{~nm}$ の波長域で解析した方が検量線評価時の標準誤差は小さ かった (第 4 表).

\section{考察}

モモの渋味成分は, カテキン類, クロロゲン酸類ならび にこれらが重合したプロアントシアニジンなどであり，こ れらのポリフェノールの重合度が高い汪ど渋味が強く, カ テキンやクロロゲン酸の単量体は渋味よりも苦味を呈する といわれている（中林，1968，1995）。したがって，モモの 渋味を正確に評価するには，カテキンやクロロゲン酸が重 合した高分子ポリフェノールの評価が必要であるが，モモ 果実の全ポリフェノール濃度と高分子ポリフェノール濃度 との相関は高く（Kubota 5，2000; 久保田ら，1992），全ポ リフェノール濃度を渋味の指標としても問題はないと考え られる。ただし，官能検査に打将全ポリフェノール濃度 と渋味との間には，Kubota（1995）の報告と同様に，本試 験でも有意な相関が認められるものの，個体差が大きいの も事実である (第 1 図)。個体差の原因には, 渋味の強いモ 
第 2 表 モモ果実の $400 \sim 1100 \mathrm{~nm}$ の 2 次微分反射スペクトルによる全ポリフェノール濃度の重回帰分析による推定

\begin{tabular}{cccccc}
\hline \hline 品種 & 試料数 & 選定波長 $(\mathrm{nm})$ & $\mathrm{R}$ & SEC & 29.2 \\
\hline 全品種 & 151 & $858,480,946,1022$ & 0.595 & 34.2 & $26-221$ \\
白鳳 & 50 & $934^{\mathrm{m}}, 478,860,576$ & 0.642 & 18.4 & $26-221$ \\
清水白桃 & 45 & $500,654,580,488$ & 0.646 & $33-148$ \\
\hline
\end{tabular}

z サンプルのポリフェノール濃度の最小值一最大值, $\mathrm{mg} ・ 100 \mathrm{~g}^{-1} \mathrm{FW}$

第 3 表 モモ果実の $1100 \sim 2500 \mathrm{~nm}$ の 2 次微分反射スペクトルによる全ポリフェノール濃度の重回帰分析による推定

\begin{tabular}{lccccc}
\hline \multicolumn{1}{c}{ 選定波長 $(\mathrm{nm})$} & $\mathrm{R}$ & $\mathrm{SEC}^{\mathrm{z}}$ & $\mathrm{r}$ & SEP $^{\mathrm{y}}$ & Bias \\
\hline $1664^{\mathrm{m}}, 1720,1950$ & 0.878 & 15.0 & 0.785 & 15.8 & -3.1 \\
$1720,1950,1794$ & 0.909 & 13.1 & 0.786 & 15.4 & -3.3 \\
$1720,1950,1794,2368$ & 0.919 & 12.5 & 0.800 & 14.7 & -3.0 \\
\hline
\end{tabular}

${ }^{\mathrm{z}} \mathrm{n}=43, \mathrm{mg} \cdot 100 \mathrm{~g}^{-1} \mathrm{FW}$

${ }^{\mathrm{y}} \mathrm{n}=35, \mathrm{mg} \cdot 100 \mathrm{~g}^{-1} \mathrm{FW}$

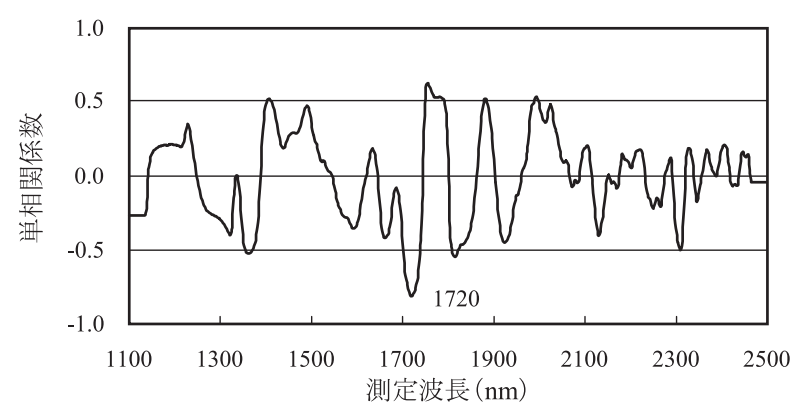

第 9 図モモ果実の 2 次微分吸光度と全ポリフェノール濃度 との単相関係数プロット

モを試食した後はしばらく舌が収斂し次サンプルの評価に 影響が出やすいことも考兄られるが，それ以外に，栽培環 境や気象条件ならびに品種によりポリフェノールの重合度 が変化することも考兄られ，この点については今後の検討 が必要である.

モモ果実中のポリフェノール濃度は, 果実発育第 2 期に 最も高く, その後は成熟にともなって徐々に低下する (Kubota 5，2000）。本試験でも果実発育第 3 期にはポリ フェノール濃度の低下が認められたが (第 2 図), これは果 実肥大に伴ら希釈効果による影響が大きかった。 したがっ て, 久保田・岩瀬（1993）も認めているょうに, 成熟時に ポリフェノール濃度が著しく高い果実は, 果実発育第 2 期 の濃度も高いものと推測される。このことは，モモ果実の ポリフェノール濃度の非破壊による測定が樹上で可能とな れば，収穫時に著しい渋味を有すると予想される果実を第 2 期の時点で選別可能であることを示唆している.

近赤外分光法によるポリフェノールの分析に関して, 後 藤ら（2001）はチャ生葉の $400 ２ 310 \mathrm{~nm}$ の反射スペクト ルからカテキン類の濃度をPLS 回帰分析で推定したとこ ろ, 全波長域を利用した検量線の推定精度が相関係数 $\mathrm{r}=0.89$ で最も優れ, 次いで $1610 \sim 2310 \mathrm{~nm}$ の波長域での 推定精度が $\mathrm{r}=0.87$ と優孔，400 700 nm の波長域でも推

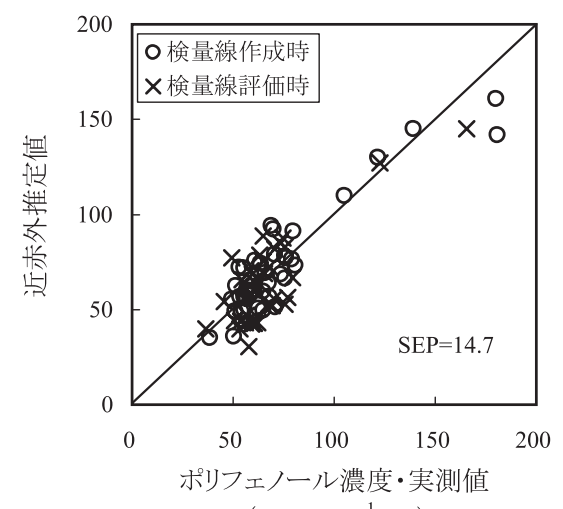

$\left(\mathrm{mg} \cdot 100 \mathrm{~g}^{-1} \mathrm{FW}\right)$

第 10 図モモ果実の $1100 \sim 2500 \mathrm{~nm}$ の 2 次微分反射スペク トルからの全ポリフェノール濃度推定值と実測值との 関係（検量線波長：1720, 1950, 1794, $2368 \mathrm{~nm}$ )

定精度が $\mathrm{r}=0.81$ と比較的高い精度で測定が可能なことを 明らかにしている。

現在，モモ選果場に導入されている糖度センサーや携帯 型の果実糖度測定装置は， 法とんどが $500 \sim 1100 \mathrm{~nm}$ の可 視・近赤外光を利用している。 したがって，この波長域で モモ果実中のポリフェノール濃度が測定できれば，潞味の 強い果実の選別も可能になる。 しかし，本試験での果実の $400 \sim 1100 \mathrm{~nm}$ の反射スペクトルからのポリフェノール濃 度の推定は誤差が大きく不可能であった。ただし，モモ果 汁の 400 1100 nm透過スペクトル解析では, $1100 〜 2500 \mathrm{~nm}$ の波長域に比べ精度は劣るものの, ポリフェノール濃度の 推定が可能であったこと, 前述した後藤ら（2001）のチャ のカテキン類濃度の推定が $400 \sim 700 \mathrm{~nm}$ の波長域で可能 であったことを総合して考光ると，この点に関する再検討 の余地が残されているものと思われる. また, 伊藤ら (1997) はカキ ‘西村早生” の洪果の判別が $710 \sim 1010 \mathrm{~nm}$ の透過 スペクトルで可能なことを報告している. ‘西村早生’の渋 果の判別が可能なのは, 自然脱渋によって褐変したタンニ ン細胞が増加することにより，透過スペクトルが大きく変 
第 4 表 モモ果実の $1100 \sim 2500 \mathrm{~nm}$ の 2 次微分反射スペクトルによる全ポリフェノール濃度のPLS 回帰分析による推定

\begin{tabular}{|c|c|c|c|c|c|c|c|}
\hline \multirow{2}{*}{ 使用波長域（nm） } & \multirow{2}{*}{$\mathrm{f}^{\mathrm{z}}$} & \multicolumn{3}{|c|}{ 検量線作成（n=43） } & \multicolumn{3}{|c|}{ 検量線評価（n=35） } \\
\hline & & $\mathrm{R}$ & SEC & $\mathrm{SECV}^{\mathrm{x}}$ & $\mathrm{r}$ & SEP & Bias \\
\hline $1150-1350,1450-1800$ & 4 & 0.879 & 14.4 & 20.9 & 0.858 & 12.5 & -5.2 \\
\hline $1150-1800$ & 4 & 0.847 & 16.1 & 22.0 & 0.825 & 13.1 & -4.1 \\
\hline $1150-2000$ & 6 & 0.945 & 9.9 & 17.6 & 0.794 & 15.3 & -2.4 \\
\hline $1150-2100$ & 8 & 0.967 & 7.6 & 19.7 & 0.807 & 15.3 & -2.4 \\
\hline
\end{tabular}

${ }^{\mathrm{z}}$ PLS 回帰分析時の因子数

$\mathrm{x}$ フルクロスバリデーション時の標準䛊差, $\mathrm{mg} ・ 100 \mathrm{~g}^{-1} \mathrm{FW}$

化するためと考学られる。モ乇の場合にも渋味の強い果実 の中には，果皮に小さな褐色斑点を形成するものがある. 第 1 表に示した果実の $400 \sim 1100 \mathrm{~nm}$ の反射スペクトルか ら作成した検量線の，第 1 もしくは第 2 波長に選定された $480 \sim 500 \mathrm{~nm}$ の波長域は褐色を反映したものであることか ら, 果皮色と渋味の関係に基づく非破壊判別の可能性も残 されているのではないかと考えられる.

一方, $1100 \sim 2500 \mathrm{~nm}$ の波長域の解析では, 果汁の透過 スペクトルならびに果実の反射スペクトルから全ポリフェ ノール濃度の推定が可能であった（+）カテキン水溶液と クロロゲン酸水溶液の透過スペクトルの解析では（第 4 図 扣よび第 5 図), 両物質の相関の高い波長域はやや異なるも のの, 両物質とも $1664 \mathrm{~nm}$ 付近の波長域との相関が最も高 く, $1730 \mathrm{~nm}$ と $2150 \mathrm{~nm}$ 付近の波長とも相関が高かった. $1664 \mathrm{~nm}$ と $2150 \mathrm{~nm}$ 付近の吸収はベンゼンの吸収と一致し, $1664 \mathrm{~nm}$ は芳香族の $\mathrm{CH}$ 伸縮運動の第1倍音, $2150 \mathrm{~nm}$ は $=\mathrm{CH}$ 伸縮 $+\mathrm{C}=\mathrm{C}$ 伸縮運動の結合音領域と推察される（尾崎・ 河田, 1996). また, $1730 \mathrm{~nm}$ はメチレン基 $\left(-\mathrm{CH}_{2}\right)$ の $\mathrm{CH}$ 伸縮運動の第 1 倍音領域と推察される（尾崎・河田，1996）. モモ果実の反射スペクトルにはいろいろな成分の吸収が含 まれるが，糖に比べ濃度の低いポリフェノールは他の成分 の吸収に影響されやすい。その中で， $1720 \mathrm{~nm}$ 付近におけ る 2 次微分吸光度はモモ果実中のポリフェノール濃度と高 い相関を示し，他の成分の影響を受けにくい波長域と推察 された。検量線の精度に測定温度や年次間差が及ぼす影響 など検討課題は多く残されているが, 全ポリフェノール濃 度を基に渋味の強い果実を非破壊選別できる可能性は高い と考劣る。な拉, 本試験では有袋栽培を行った果皮と果肉 が白いモモを供試したが，無袋栽培の果皮の赤いモモや果 肉が赤いネクタリンなどは，果皮や果肉にポリフェノール 成分としてアントシアニンを豊富に含むので，本試験の結 果は適用できない可能性があり, この点については更に検 討する必要がある.

今後, 渋味の非破壊判別技術を選果場で実用化するには, $1100 \mathrm{~nm}$ 以上の波長域が測定可能な光センサーの開発が望 まれるが，現在既に $1100 \mathrm{~nm}$ 以上の波長域の測定が可能な 小型の装置も販売されているので，これらを利用したモモ の渋味判別装置の開発が可能と考えられる. 光線透過度が 低い $1100 \sim 2500 \mathrm{~nm}$ のスペクトル測定に打いては, 果実表
面の情報に依存する割合が高くなるが，モモ果実中のポリ フェノール濃度が果肉よりも果皮の方が高い（久保田ら， 1992; Tomas-Barberan ら，2001）ことを勘案すると，モモの ポリフェノールの分析にはむしろ好都合とも考えられる. 選果場に打ける全量検査は無理にしても，これらの装置に より生産者別の抜き取り検査を実施する際に，近赤外分光 法によるモモの渋味の非破壊判別の実用化は可能と考えら れる。

\section{摘 要}

モモ果実の渋味の近赤外分光法による非破壊測定の方法 について検討した。モモの渋味は果肉中の全ポリフェノー ル濃度と相関が高く，全ポリフェノール濃度が $100 \mathrm{~g}$ 当た り約 $110 \mathrm{mg}$ 以上で強い渋味を感じた。 そこで，モモ果実中 の全ポリフェノール濃度の推定を $400 \sim 1100 \mathrm{~nm}$ の反射ス ペクトルから試みたが，誤差が大きく測定不可能と考光ら れた. しかし，モモのポリフェノールの主要な構成成分で あるカテキンとクロロゲン酸水溶液の $1100 ２ 500 \mathrm{~nm}$ の透 過スペクトルを解析すると, $1664 \mathrm{~nm}$ と $1730 \mathrm{~nm}$ 付近に相 関の高い波長域が存在した。そこで，モモ果実の 1100 $2500 \mathrm{~nm}$ の反射スペクトルによる解析を行ったところ, $1720 \mathrm{~nm}$ 付近に全ポリフェノール濃度と相関の高い波長域 が存在し，重回帰分析による全ポリフェノール濃度の推定 精度は SEP $=14.7 \mathrm{mg} ・ 100 \mathrm{~g}^{-1} \mathrm{FW}$ と比較的高かった。 これ らの結果から，1100〜2500 nm の反射スペクトルを測定す ることによって，モモ果実の渋味を非破壊的に判別できる 可能性が高いと考えられた.

謝 辞 果実の長波長域での近赤外スペクトルの測定に 御協力頂いた前山口県農業試験場総括主任の吉松敬祐氏, ならびに本稿の御高閲を頂いた岡山大学農学部教授久保田 尚浩博士に感謝の意を表します。

\section{引用文献}

後藤 正・小柳津 勤・中村順行・夏賀元康. 2001. 近赤 外法によるチャ生葉のカテキン類含量の定量. 非破壊 計測シンポ講要. $17: 188-189$.

伊藤 茂・大竹良知・鬼頭勇夫. 1997. 近赤外分光法によ る不完全甘ガキ「西村早生」の渋果判別. 愛知農総試 研報. 29: 213-218. 
Kubota, N. 1995. Phenolic content and L-phenylalanine ammonia-lyase activity in peach fruit. p. 81-95. In: H. F. Linskens and J. F. Jackson (eds.). Modern methods of plant analysis. Vol. 18. Fruit analysis. Springer-Verlag, Berlin Heidelberg.

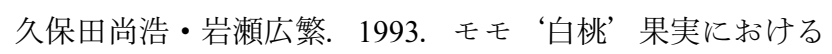
渋味発生と主枝の生育異常との関係. 岡山大農学報. 81: $37-42$.

久保田尚浩・川尾尚史・島村和夫. 1990. モモ果実のポリ フェノール含量に及ぼす土㙋の乾燥ならびに気温の影 響. 生物環境調節. 28: 141-146.

久保田尚浩 - 三村博美 - 島村和夫. 1988. 土壌の乾燥と湛 水がモモ果実のフェノール含量に及ぼす影響. 岡山大 農学報. 71: 17-21.

Kubota, N., H. Mimura and K. Shimamura. 2000. Differences in phenolic levels among mature peach and nectarine cultivars and their relation to astringency. J. Japan. Soc. Hort. Sci. 69: 35-39.

久保田尚浩 - 三村博美 - 薬師寺浩子 - 島村和夫. 1992. 乇
モ果実に打ける渋味発生の果樹園，樹体执よび果実内 部位による差異. 岡山大農学報. 79: 45-51.

久保田尚浩・高木真吾・工藤正吾. 1993. モモ果実のポリ フェノール含量に及ぼす樹勢の影響. 園学雑. 62: 8388.

京都大学農学部農芸化学教室編. 1964. 新改版農芸化学実 験書 (増補) 第三巻. p. 1093 . 産業図書. 東京.

中林敏郎. 1968. 果実扣よびそ菜類のタンニン成分 (第 1 報) バラ科果樹果実のタンニン成分. 日食工誌. 15: 73-78. 中林敏郎. 1995. ポリフェノール成分と変色. p. 1-157. 木村 進・中林敏郎・加藤博通編. 食品の変色の化学. 光琳. 東京.

尾崎幸洋・河田 聡編. 1996. 近赤外分光法. p. 1-224. 学 会出版センタ一. 東京.

Tomas-Barberan, F. A., M. I. Gil, P. Cremin, A. L. Waterhouse, B. Hess-Pierce and A. A. Kader. 2001. HPLC-DAD-ESIMS analysis of phenolic compounds in nectarines, peaches, and plums. J. Agric. Food Chem. 49. 4748-4760. 